\title{
TGX-221 inhibits proliferation and induces apoptosis in human glioblastoma cells
}

\author{
XUE YANG, JI-AN YANG, BAO-HUI LIU, JIAN-MING LIAO, FAN-EN YUAN, \\ YIN-QIU TAN and QIAN-XUE CHEN
}

\author{
Department of Neurosurgery, Renmin Hospital of Wuhan University, Wuchang, Wuhan, Hubei 430060, P.R. China
}

Received March 24, 2017; Accepted September 4, 2017

DOI: 10.3892/or.2017.5991

\begin{abstract}
Glioblastoma is the most common type of primary brain tumor in adults, with high mortality and morbidity rates. More effective therapeutic strategies are imperative. Previous studies have shown that the known p110- $\beta$-selective inhibitor TGX-221 blocks the activation of PKB/Akt in PTEN-deficient cells. We treated U87 and U251 glioblastoma cells with TGX-221 to determine the effect of TGX-221. We performed a Cell Counting Kit-8 (CCK-8) test, EDU staining and cell cycle distribution analysis and found that TGX-221 inhibited glioblastoma cell proliferation. Next, the effect of TGX-221 on cell apoptosis was investigated using flow cytometry. These results demonstrated that TGX-221 induced apoptosis in glioblastoma cells. Moreover, migration and invasion assays revealed that TGX-221 inhibited human glioblastoma cell migration and invasion. Collectively, our study revealed that TGX-221 could inhibit proliferation and induce apoptosis in glioblastoma cells.
\end{abstract}

\section{Introduction}

Glioblastoma is the most common type of primary brain tumor in adults. This highly malignant tumor creates a serious social and economic burden and is associated with high mortality and morbidity (1). Although multimodal treatment consisting of surgery, radiation therapy and chemotherapy has been used, glioblastoma still exhibits a poor prognosis, with a less than 12-month survival period (2). In addition, less than 5\% of patients with glioblastoma survive more than 5 years after diagnosis (3). Thus, more effective therapeutic strategies are imperative.

Class I phosphatidylinositol 3-kinases (PI3Ks) play critical roles in a variety of cellular processes, such as differentiation, metabolism, migration and survival (4). The PI3K family is subdivided into 3 classes, and class I PI3K is further divided

Correspondence to: Professor Qian-Xue Chen, Department of Neurosurgery, Renmin Hospital of Wuhan University, 9 Zhangzhidong Road and 238 Jiefang Road, Wuchang, Wuhan, Hubei 430060, P.R. China

E-mail: chenqx666@163.com; chenqx666@sohu.com

Key words: TGX-221, glioblastoma, apoptosis, proliferation into 4 members (p110 $\alpha, \mathrm{p} 110 \beta, \mathrm{p} 110 \gamma$ and $\mathrm{p} 110 \delta)$ (5). Previous studies have revealed that $\mathrm{p} 110 \beta$ can be activated by growth factor receptors and $\mathrm{G}$ protein-coupled receptors, and its overexpression is capable of transforming cells (6). In addition, the known p110- $\beta$-selective inhibitor TGX-221 blocked activation of PKB/Akt in PTEN-deficient cells $(7,8)$. For example, p110 $\beta$ expression was significantly increased in malignant prostate tissues compared with that in their surrounding non-malignant counterparts, and its mRNA levels were correlated with disease progression in prostate cancer patients (9). Compared with the solvent control, TGX-221 significantly decreased xenograft tumor growth in nude mice (10). Furthermore, this result was supported by other groups using transgenic mouse models $(11,12)$ and cell culture models $(13)$

Previous studies have revealed that PTEN restoration and PIK3CB knockdown synergistically suppressed glioblastoma growth in vitro and in xenografts (7). However, whether TGX-221 inhibits proliferation and induces apoptosis of glioblastoma cells has not been well studied. Thus, we treated U87 and U251 cells with TGX-221 to determine the effect of TGX-221 on glioblastoma cells.

\section{Materials and methods}

Cell culture. The human glioblastoma cell lines U251 and U87 were acquired from the State Key Laboratory of Molecular Biology, Institute of Biochemistry and Cell Biology, Shanghai Institutes for Biological Sciences, Chinese Academy of Sciences (Shanghai, China). The cells were cultured in Dulbecco's modified Eagle's medium (DMEM) containing $10 \%$ fetal bovine serum and incubated at $37^{\circ} \mathrm{C}$ in a humidified atmosphere containing 5\% carbon dioxide. DMEM was acquired from GINOM Co., Ltd. (Guangzhou, China). TGX-221 was purchased from Selleckchem (Houston, TX, USA) and dissolved in dimethyl sulfoxide (DMSO), which was a product purchased from Sigma-Aldrich (St. Louis, MO, USA).

CCK-8 assay. Cell viability was assessed using Cell Counting Kit-8 (CCK-8) according to the manufacturer's instructions. CCK-8 was purchased from Dojindo China Co., Ltd. (Shanghai, China). Approximately $8 \times 10^{3}$ cells were seeded in a volume of $100 \mu \mathrm{l}$ of DMEM into each well of a 96 -well plate. TGX-221 was added to the medium and evaluated at different 

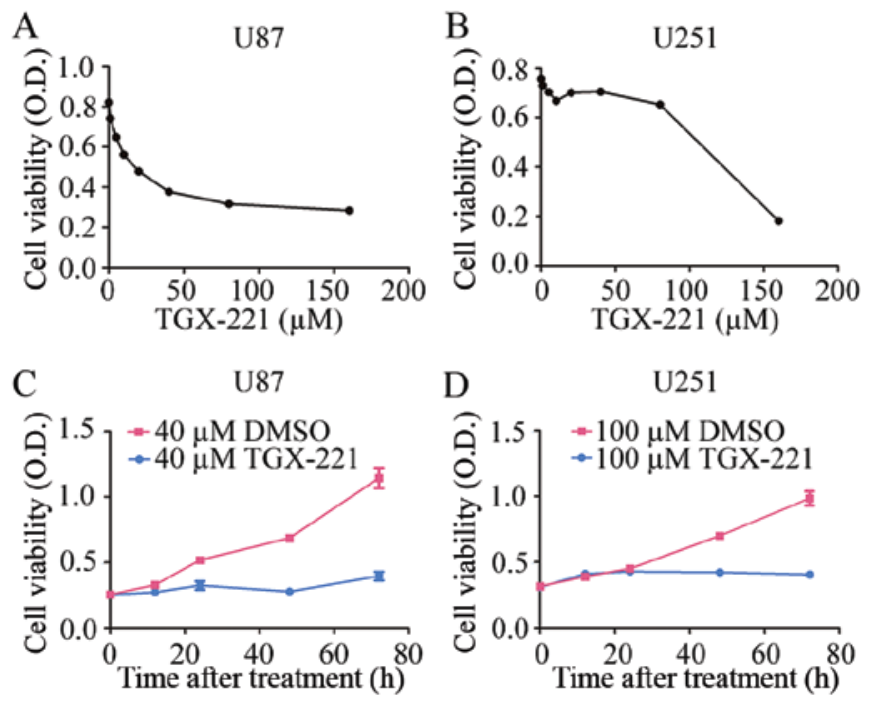

Figure 1. TGX-221 suppresses the viability of glioblastoma cells. (A) U87 cells were exposed to culture medium containing various concentrations of TGX-221 for $48 \mathrm{~h}$, and (B) a similar protocol was performed using the U251 cells. (C) U87 cells were treated with $40 \mu \mathrm{M}$ TGX-221 at different time-points. (D) U251 cells were treated with $100 \mu \mathrm{M}$ TGX-221 at different time-points. The cell viability was assessed using the CCK-8 assay.

concentrations at a single time-point or at different time-points at a single concentration. In addition, $100 \mu 1$ of fresh medium containing $5 \mu \mathrm{l}$ of CCK-8 solution was added into each well and incubated at $37^{\circ} \mathrm{C}$ for $30 \mathrm{~min}$. The absorbance at $450 \mathrm{~nm}$ was measured using a spectrophotometric plate reader. Each group was assessed in triplicate.

5-Ethynyl-2'-deoxyuridine (EdU) staining. The Cell-Light EdU DNA Cell Proliferation kit was purchased from RiboBio Co., Ltd. (Guangzhou, China) and used according to the manufacturer's instructions. Approximately $8 \times 10^{3}$ cells were seeded in a volume of $100 \mu \mathrm{l}$ of DMEM into each well of a 96 -well plate. The medium was mixed with TGX-221 at different concentrations, and the cells were evaluated $48 \mathrm{~h}$ after exposure to TGX-221. The cells were treated with $50 \mu \mathrm{mol} / 1$ EdU for $12 \mathrm{~h}$ at $37^{\circ} \mathrm{C}$. After fixation with $4 \%$ paraformaldehyde for $15 \mathrm{~min}$, the cells were treated with $0.5 \%$ Triton X-100 for $20 \mathrm{~min}$ and rinsed with phosphate-buffered saline (PBS) 3 times. Next, the cells were incubated with $100 \mu \mathrm{l}$ of $1 \mathrm{X}$ Apollo ${ }^{\circledR}$ reaction cocktail for $30 \mathrm{~min}$, and the cell nuclei were stained for $30 \mathrm{~min}$ with $5 \mu \mathrm{g} / \mathrm{ml}$ Hoechst 33342. Fluorescence images of the EdU and Hoechst in the cells were captured using a fluorescence microscope (Olympus, Tokyo, Japan). The number of EdUand DAPI-positive cells was quantified using ImageJ software, and the EdU-labeling index was calculated as the ratio of the number of EdU-positive cells to the number of DAPI-positive cells.

Flow cytometry for cell apoptosis and cell cycle distribution analysis. The effects of TGX-221 on apoptosis and cell cycle distribution were determined using the Annexin V-FITC/propidium iodide (PI) apoptosis and cell cycle kit independently, according to the manufacturer's instructions from MultiSciences Biotech (Hangzhou, China). The cells were examined after $48 \mathrm{~h}$ following exposure to TGX-221 at different concentrations. At the end of the treatment period, $3 \times 10^{5}$ or more cells were trypsinized, collected by centrifugation at 1,000 rpm for $5 \mathrm{~min}$ and rinsed with cold
PBS. Next, the corresponding dyes and solution were added and incubated according to the manufacturer's instructions. Cell apoptosis and cell cycle distribution were analyzed using a flow cytometer (Becton-Dickinson, Franklin Lakes, NJ, USA), and the data were analyzed using FlowJo software (version 7.6).

Migration and invasion assays. Migration and invasion assays were performed using a Transwell chamber with an $8.0-\mu \mathrm{m}$ pore polycarbonate membrane. The cells were seeded into the top chambers containing the membranes, which were either coated or not with Matrigel for migration and invasion assays, respectively. Then, the chambers were placed into a 24-well plate, and medium containing $10 \%$ fetal bovine serum was added. The cells were fixed and stained with crystal violet, which penetrated the underside surfaces of the membranes. Subsequently, the cells were quantified under a microscope. The assays were performed 3 times.

Western blot analysis. Cell proteins were extracted with RIPA lysis buffer and assessed using the standard BCA method (Beyotime Institute of Biotechnology, Jiangsu, China). Equal amounts of protein were separated using SDS-PAGE and electroblotted onto polyvinylidene difluoride membranes (Millipore Corp., Bedford, MA, USA). The membranes were blocked in TBS containing $0.1 \%$ Tween-20 and 5\% powdered milk, and incubated at $4{ }^{\circ} \mathrm{C}$ overnight with primary antibodies against cleaved caspase-3, caspase-3, Bcl-2, Lc-3b, MMP9 and $\beta$-actin. Then, the membranes were incubated in the secondary antibody Alex Fluor 680/790-labeled goat antirabbit IgG (LI-COR Biosciences, Lincoln, NE, USA) for $1 \mathrm{~h}$. Subsequently, the blots were visualized using the LI-COR Odyssey Infrared Imaging System.

Statistical analyses. All experimental results are expressed as the mean \pm SD. A Student's t-test was performed to determine the significance between two mean values. The results were considered significant at P-values of $<0.05$. 
A

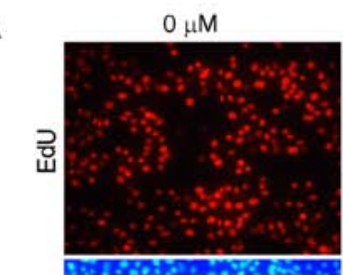

离
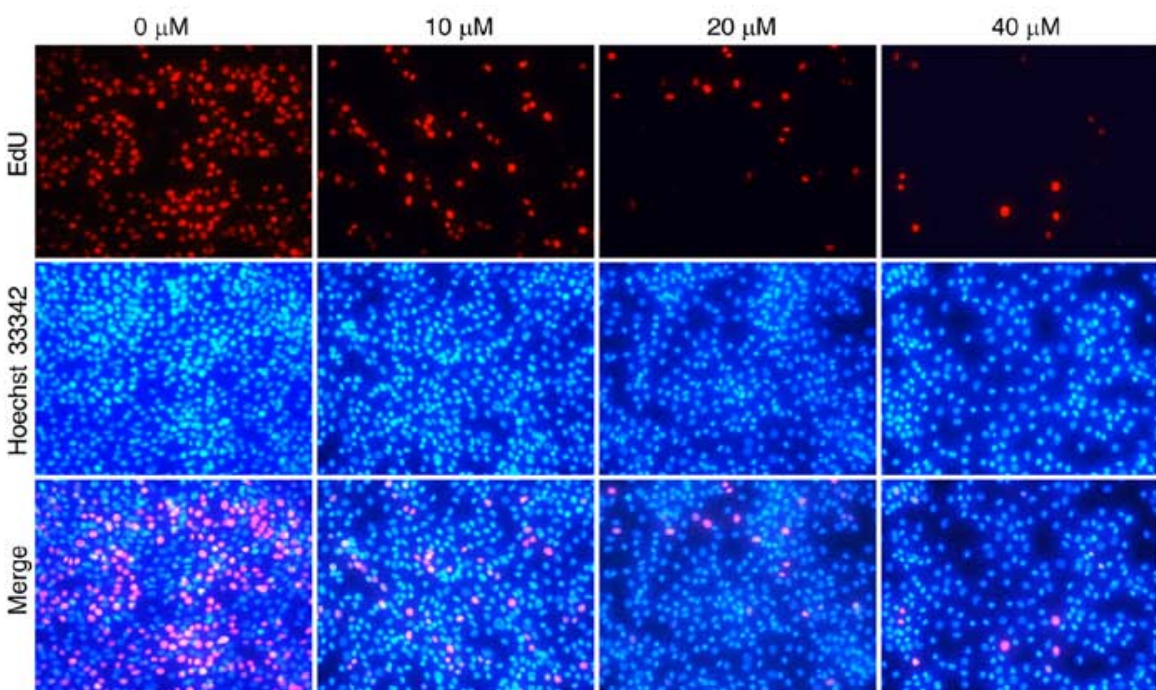

B
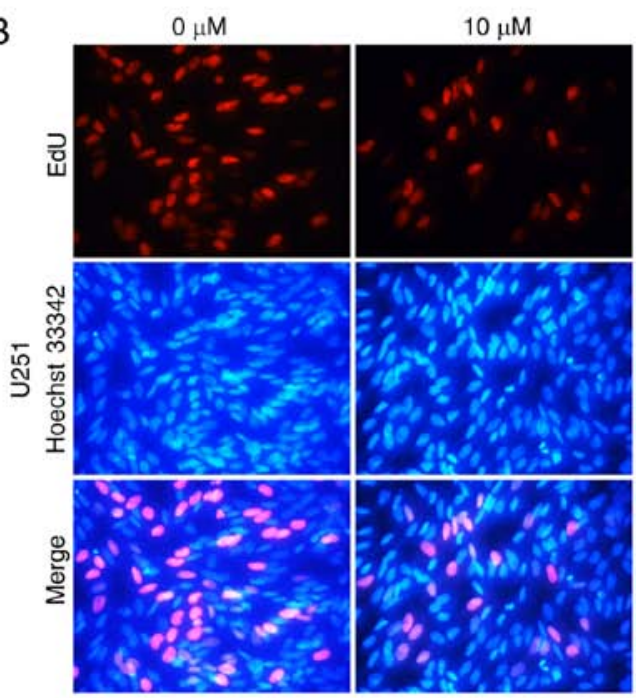

U87

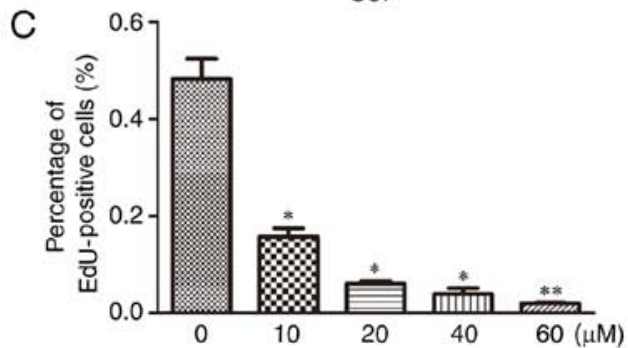

$20 \mu \mathrm{M}$
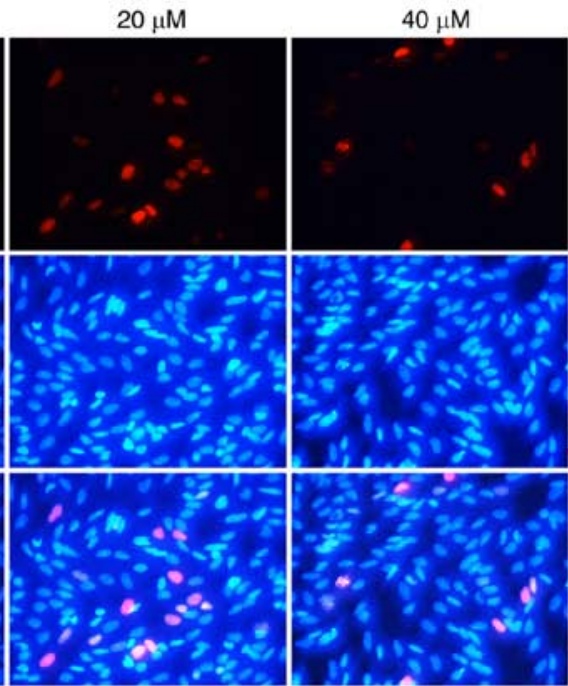

U251

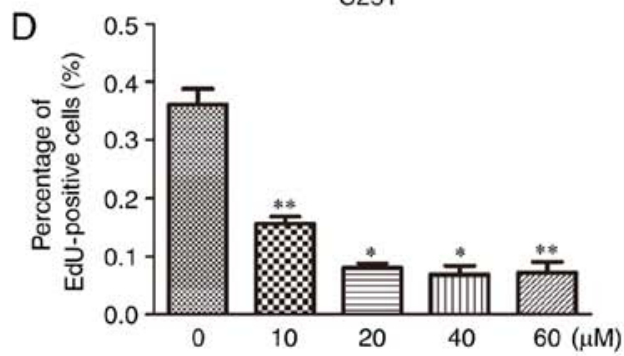

Figure 2. TGX-221 inhibits glioblastoma cell proliferation. Proliferating U87 cells were treated with different concentrations $(0,10,20,40$ and $60 \mu \mathrm{M})$ of TGX-221. (A) Next, the cells were labeled with EdU, and the cell nuclei were stained with Hoechst 33342 . (B) U251 cells were treated using the same protocol. $(\mathrm{C}$ and $\mathrm{D})$ The percentage of EdU-positive U87 and U251 cells were quantified. ${ }^{*} \mathrm{P}<0.05,{ }^{* *} \mathrm{P}<0.01$.

\section{Results}

TGX-221 inhibits glioblastoma cell proliferation. To confirm the effect of TGX-221 on glioblastoma cell proliferation, we performed the CCK-8 assay using different concentrations of TGX-221 in U87 and U251 cells. As shown in Fig. 1A and B, TGX-221 significantly inhibited the viability of U87 and U251 cells in a dose-dependent manner. The $\mathrm{IC}_{50}$ values of TGX-221 in $\mathrm{U} 87$ and $\mathrm{U} 251$ cells were $\sim 40$ and $100 \mu \mathrm{M}$, respectively. We then performed the CCK-8 assay at different time-points with the $\mathrm{IC}_{50}$ values of TGX-221. Glioblastoma cell proliferation was inhibited significantly by TGX-221 in a time-dependent manner (Fig. 1C and D).

To further confirm the inhibitory effect of TGX-221 on cell proliferation in glioblastoma cells, we performed the EdU assay in both U87 and U251 cells (Fig. 2A and B). A significant inhibition of cell proliferation was observed in both U87 and U251 cells in a dose-dependent manner. With an increase in TGX-221 concentration, the number of cell nuclei with thymidine analog incorporation was decreased. The total percentage of stained nuclei in cells treated with TGX-221 was lower than that in the cells treated with DMSO (Fig. 2C and D). 
A
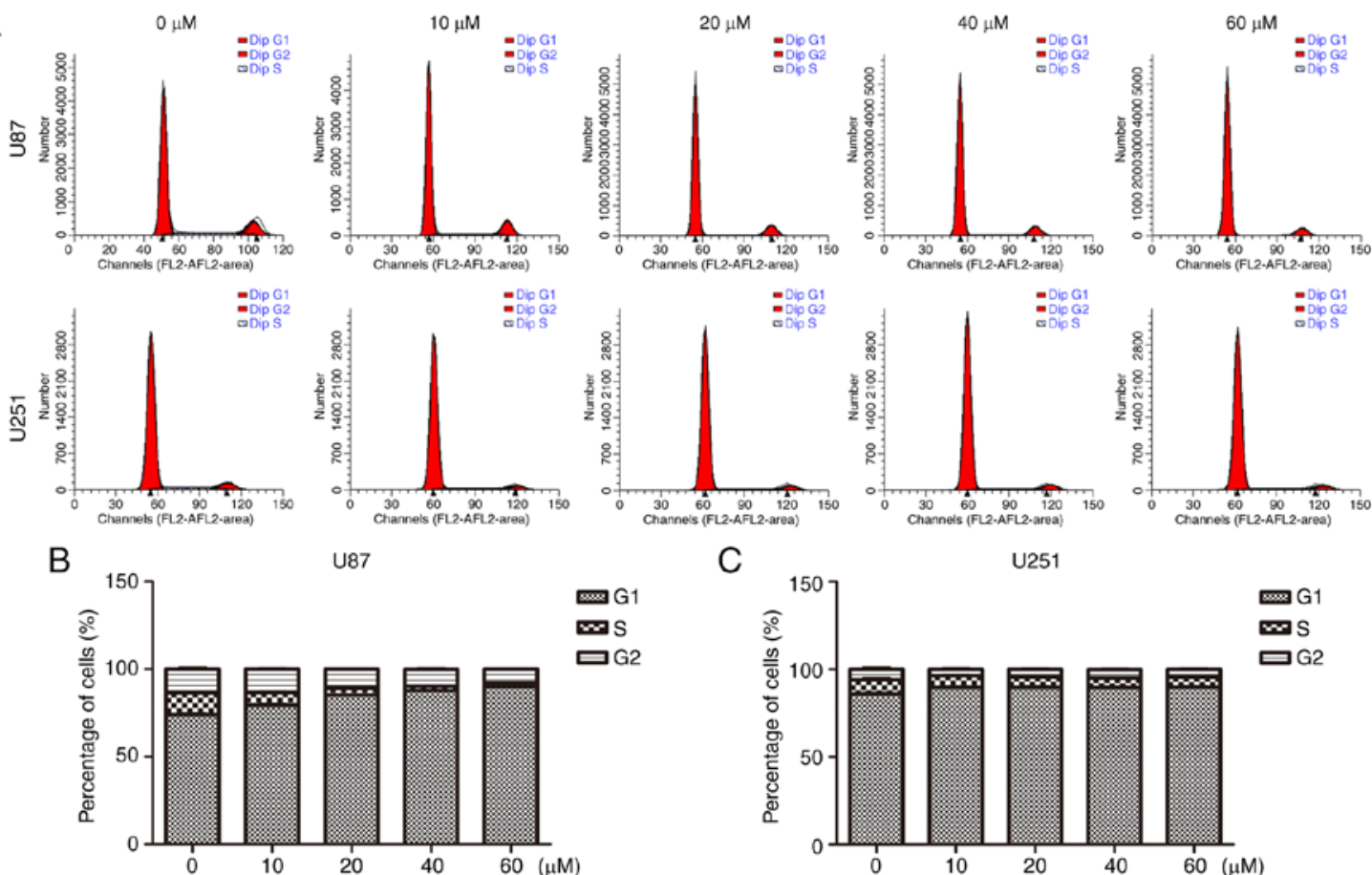

C

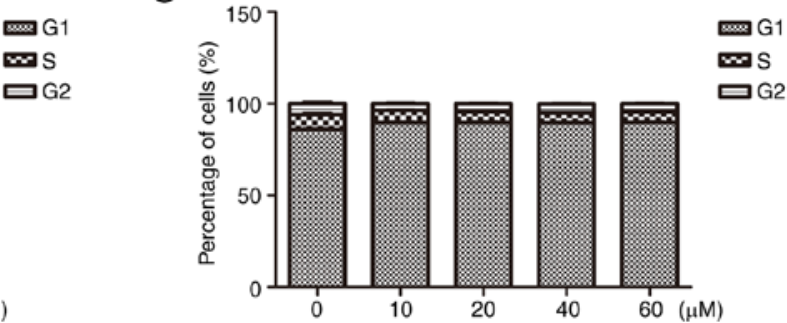

Figure 3. TGX-221 affects the cell cycle progression of glioblastoma cells. (A) U87 and U251 cells were treated with different concentrations $(0,10,20,40$ and $60 \mu \mathrm{M}$ ) for $48 \mathrm{~h}$, and the DNA content was analyzed using flow cytometry. (B and C) The percentage of cells in the S and G2 phases of the cell cycle was calculated.

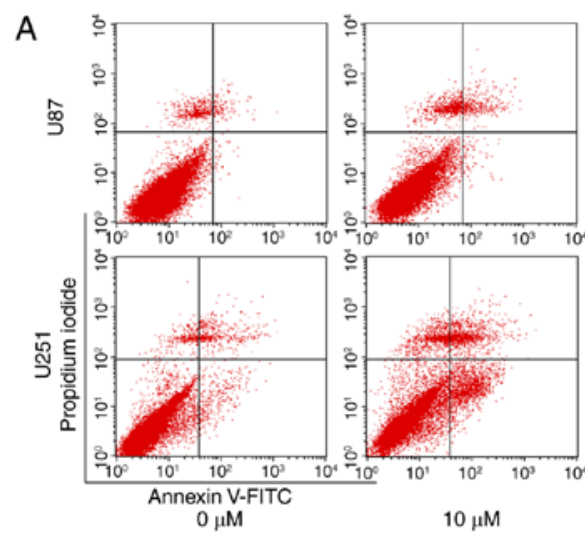

B

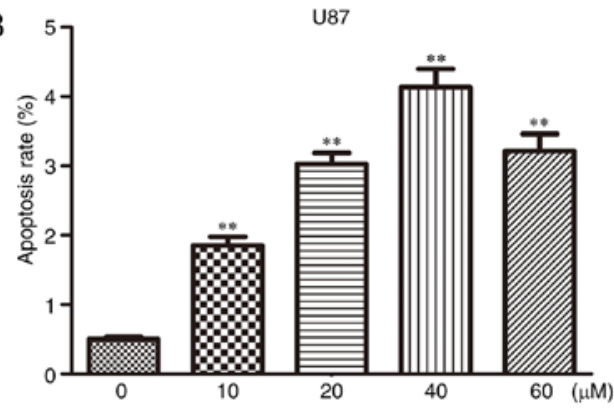

C

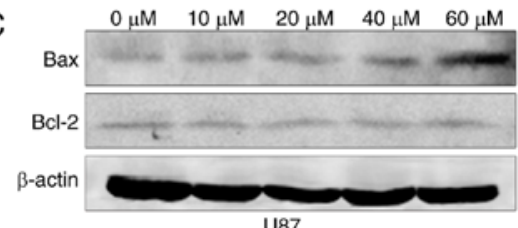

U87
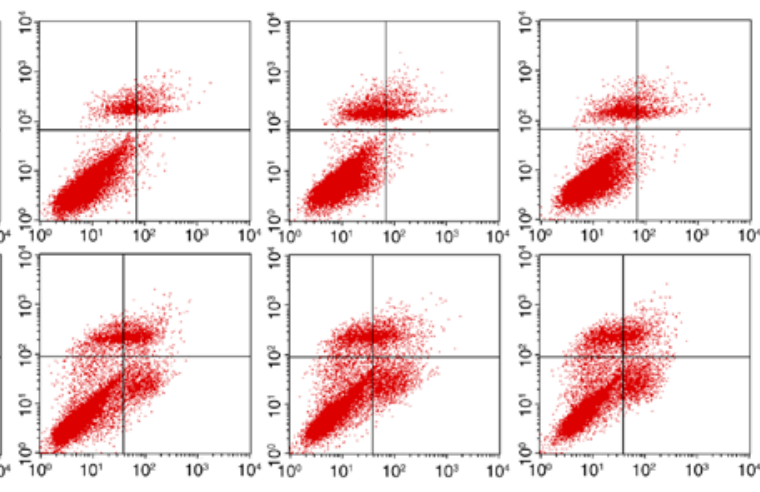

$20 \mu \mathrm{M}$

$40 \mu \mathrm{M}$
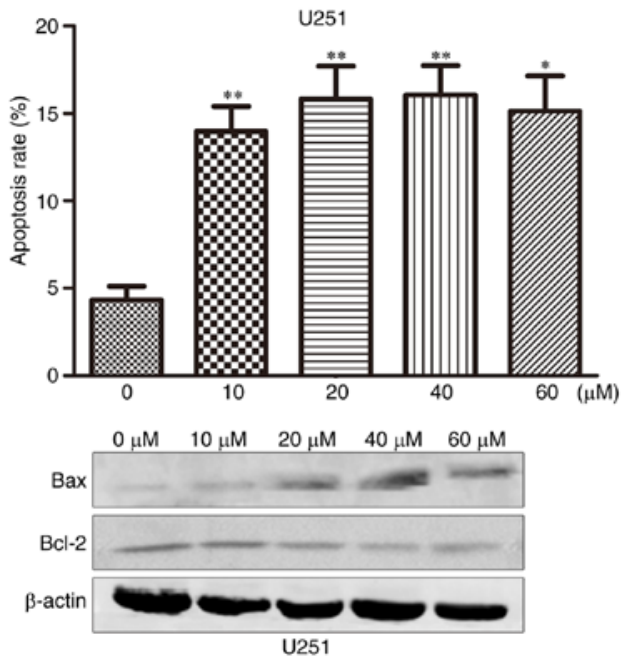

Figure 4. TGX-221 induces apoptosis in glioblastoma cells. (A) Apoptosis of U87 and U251 cells was analyzed using Annexin V-FITC/PI staining after a 48-h treatment with TGX-221 at different concentrations $(0,10,20,40$ and $60 \mu \mathrm{M})$. (B) Apoptosis rates of U87 and U251 cells at different concentrations were compared. The data represent the mean $\pm \mathrm{SD} ;{ }^{*} \mathrm{P}<0.05,{ }^{* *} \mathrm{P}<0.01$. (C) After treatment of U87 and U251 cells with different concentrations $(0,10,20,40$ and $60 \mu \mathrm{M})$, the expression of Bax was increased while the expression of Bcl-2 was decreased and with increasing TGX-221 concentrations, respectively. 


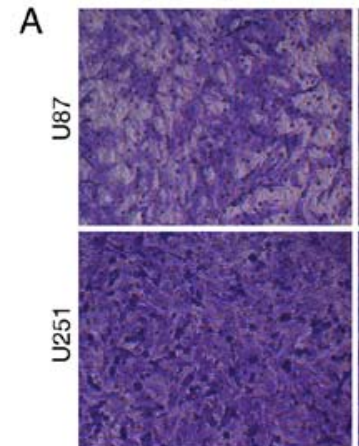

$0 \mu \mathrm{M}$

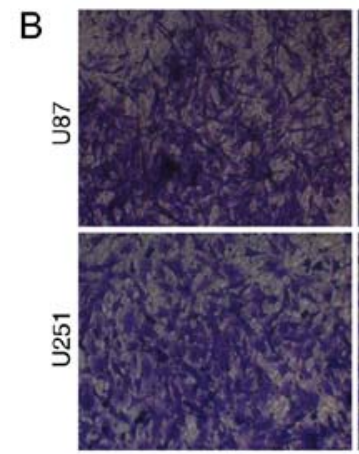

$0 \mu \mathrm{M}$

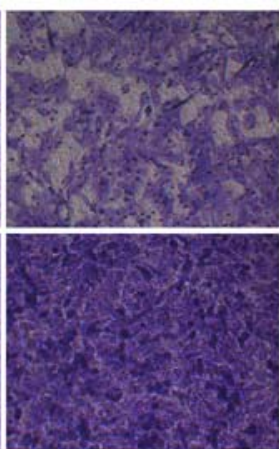

$10 \mu \mathrm{M}$

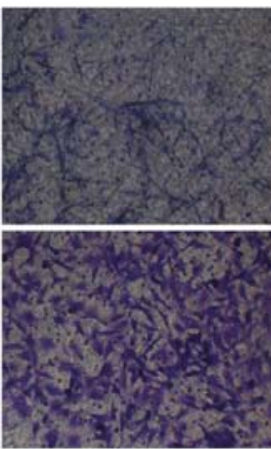

$10 \mu \mathrm{M}$

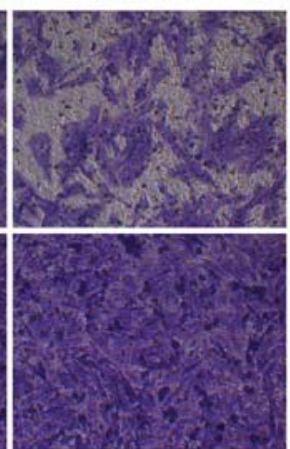

$20 \mu \mathrm{M}$

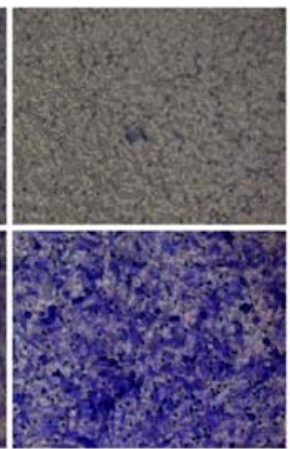

$20 \mu \mathrm{M}$

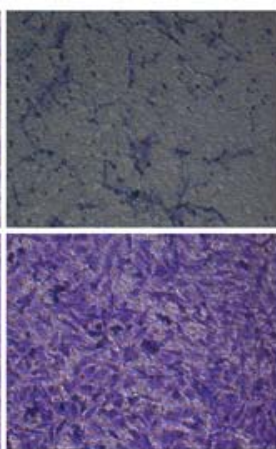

$40 \mu \mathrm{M}$

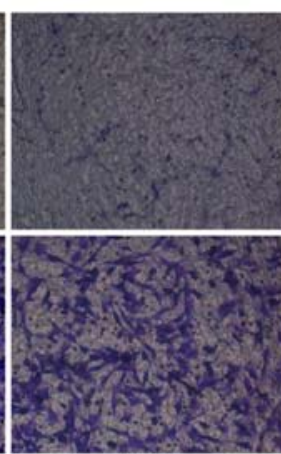

$40 \mu \mathrm{M}$

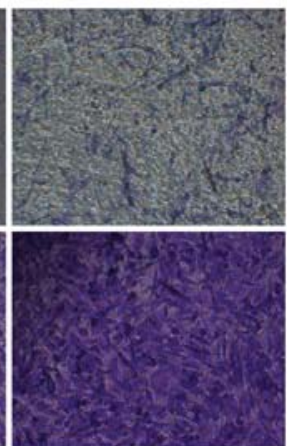

$60 \mu \mathrm{M}$

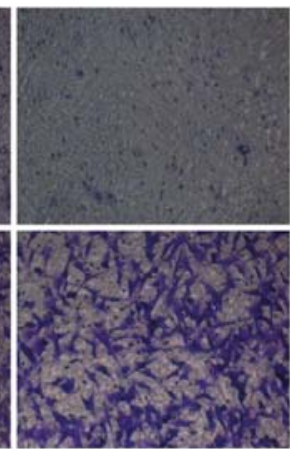

$60 \mu \mathrm{M}$
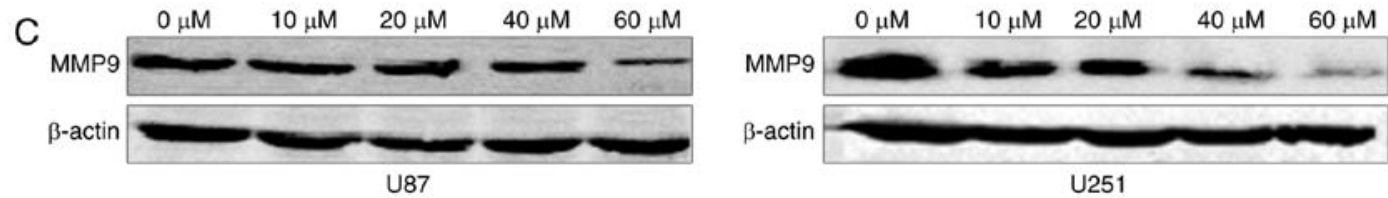

Figure 5. TGX-221 inhibits glioblastoma cell migration and invasion. (A) The migration ability gradually decreased in U87 and U251 cells with increasing concentrations of TGX-221. (B) The invasion ability of glioblastoma cells gradually decreased in a dose-dependent manner. (C) MMP9 significantly decreased with increasing concentrations of TGX-221 in U87 and U251 cells.

In addition, we performed flow cytometry to analyze the cell cycle distribution. As shown in Fig. 3, U87 and U251 cells were cultured with TGX-221 for $48 \mathrm{~h}$. The percentage of cells in the G1 phase was increased compared with that in the control groups. The percentage of cells in the $\mathrm{S}$ and G2 phases was decreased, which suggested that TGX-221 inhibited glioblastoma cell proliferation. Importantly, the percentage of S and G2 phases decreased with an increase in TGX-221 concentration in glioblastoma cells.

TGX-221 induces apoptosis in glioblastoma cells. The effect of TGX-221 on cell apoptosis was investigated using flow cytometry. The apoptosis rates at $48 \mathrm{~h}$ after treatment at different concentrations $(0,10,20,40$ and $60 \mu \mathrm{M})$ are shown in Fig. 4A and B. We found that the apoptosis rate increased significantly with increasing TGX-221 concentrations.

TGX-221 inhibits glioblastoma cell migration and invasion. To examine whether TGX-221 inhibits the migration and invasion of glioblastoma cells, we performed a migration and invasion assay in U87 and U251 cells at different concentrations $(0,10,20,40$ and $60 \mu \mathrm{M})$. We found that TGX-221 inhibited glioblastoma cell migration and invasion (Fig. 5A and B). These results were further confirmed using western blot analyses. Furthermore, we demonstrated that MMP9 gradually decreased with increasing concentrations of TGX-221 (Fig. 5C).

\section{Discussion}

The PI3K family can be divided into 3 classes according to their homology and function (14). Class I PI3Ks consists of two groups (A and B), and previous research has shown that only Class IA enzymes are expressed in human types of cancer. Class IA is a heterodimeric protein consisting of a p110-kDa catalytic subunit and a p85-kDa regulatory subunit. The p85 regulatory subunit inhibits the catalytic activity of the p110 subunit in quiescent cells (15). Previous studies have demonstrated that activating point mutations or amplifications in the PIK3CA gene are present in many types of human cancer (16-21). Moreover, these findings revealed that an aberration of PIK3CA affects the occurrence and development of human types of cancer. Furthermore, PIK3CB has been demonstrated to play an important role in PI3K/AKT signaling in glioblastomas (7). Recent studies examining mutant PIK3CA also revealed that p110 $\alpha$ was the most effective therapeutic target in many human tumors. However, PTEN-deficient types of cancer appear to be dependent on PIK3CB, but not PIK3CA. Several studies have confirmed these findings in many human tumor cells, including prostate, glioma, breast and endometrial 
cancer cells (22-25). In a previous study, we used the combined treatment of PTEN restoration and PIK3CB-siRNA and demonstrated that it was an effective gene therapy approach for PTEN-deficient glioblastomas (7).

We examined the role of the PI3K p110 $\beta$ isoform in signaling pathways and found that TGX-221 inhibited p110 $\beta$ based on a detailed structure and function analysis of LY294002. TGX-221 exhibited a >1,000-fold selectivity for PI3K p110 $\beta$ over a broad range of protein kinases. Similar to LY294002, the concentration of ATP affected the inhibitory effects of TGX-221 (26). Furthermore, TGX-221 consists of a chiral center with an aniline moiety, and uses racemic material to exert its functions (27). TGX-221 has been successfully used to inhibit p110 $\beta$ activity in some human tumors. Recent studies also demonstrated that TGX-221 effectively blocked tumor growth in prostate cancer xenograft mouse (10), transgenic mouse $(11,12)$ and cell culture models $(13)$. In the present study, we investigated U87 and U251 cells treated with TGX-221 to examine the effect of TGX-221 in glioblastoma cells. We hypothesized that TGX-221 inhibited proliferation and induced apoptosis in human glioblastoma cells based on the findings obtained in previous studies (10-13).

Our results indicated that TGX-221 inhibited proliferation, migration and invasion, and induced apoptosis. In addition, we found that U87 cells were more sensitive to TGX-221 than U251 cells. A previous study revealed that PIK3CB knockdown suppressed glioblastoma growth with PTEN restoration in vitro and in xenografts (7). Thus, TGX-221 could be more effective in U87 cells potentially due to their lack of PTEN expression.

Previous studies have provided some clues regarding the mechanism of TGX-221 (27). First, TGX-221 is an inhibitor of p110 $\beta$, which participates in the PI3K/Akt signaling pathway (5). Thus, we proposed that the effect of TGX-221 may potentially involve the PI3K/Akt signaling pathway. Akt regulates cell apoptosis and survival $(4,28)$, and Akt may exert its effects via an $\mathrm{NF}-\kappa \mathrm{B}$ signaling pathway to affect cell survival. The mechanistic effects observed were similar to our results. Thus, TGX-221 may induce apoptosis and inhibit proliferation in glioblastoma cells via the PI3K/Akt signaling pathway. Many studies have illustrated that $\mathrm{P} 110 \beta$ plays a role in thrombosis and stenosis reduction (29-31). The effect of TGX-221 in thrombosis and stenosis potentially occurs via the regulation of ERK phosphorylation (31). ERK can affect cell proliferation via the MAPK signaling pathway. Thus, TGX-221 may also affect cell proliferation via the MAPK signaling pathway. Previous studies have proposed that $\mathrm{p} 110 \beta$ plays an important role in insulin signaling (32-34). Moreover, some studies have also demonstrated that $\mathrm{p} 110 \beta$ can be activated by GPCRs (35-36). Furthermore, p110 $\beta$ exhibited different requirements for Ras activation (6). On the basis of these studies, we found that $110 \beta$ affected cell apoptosis, the cell cycle, cell proliferation and cell survival via several pathways. Thus, TGX-221 may inhibit p110 $\beta$ to affect the biological behaviors of glioblastoma cells.

Although we obtained some results that can explain the effects observed with TGX-221, the present study has several limitations. First, we only demonstrated the effect of TGX-221, but we did not examine its underlying mechanism. Furthermore, we only performed our studies using U87 and
U251 cells, and did not examine the effect of TGX-221 in vivo. Finally, we did not have sufficient clinical evidence to demonstrate our results. However, our results are credible and aligned with our expectations.

Collectively, our study illustrated that TGX-221 can inhibit proliferation and induce apoptosis in human glioblastoma cells, which may represent a promising strategy for the treatment of glioblastoma.

\section{Acknowledgements}

The present study was supported by the National Natural Science Foundation of China (nos. 81372683 and 81572489) (to Q.-X.C.), and (no. 81502175) (to B.-H.L.).

\section{References}

1. Louis DN, Ohgaki H, Wiestler OD, Cavenee WK, Burger PC, Jouvet A, Scheithauer BW and Kleihues P: The 2007 WHO classification of tumours of the central nervous system. Acta Neuropathol 114: 97-109, 2007.

2. Davis FG, McCarthy BJ, Freels S, Kupelian V and Bondy ML: The conditional probability of survival of patients with primary malignant brain tumors: Surveillance, epidemiology, and end results (SEER) data. Cancer 85: 485-491, 1999.

3. Ostrom QT, Gittleman H, Farah P, Ondracek A, Chen Y, Wolinsky Y, Stroup NE, Kruchko C and Barnholtz-Sloan JS: CBTRUS statistical report: Primary brain and central nervous system tumors diagnosed in the United States in 2006-2010. Neuro Oncol 15 (Suppl 2): ii1-ii56, 2013.

4. Vivanco I and Sawyers CL: The phosphatidylinositol 3-Kinase AKT pathway in human cancer. Nat Rev Cancer 2: 489-501, 2002.

5. Vanhaesebroeck B, Stephens L and Hawkins P: PI3K signalling: The path to discovery and understanding. Nat Rev Mol Cell Biol 13: 195-203, 2012.

6. Kang S, Denley A, Vanhaesebroeck B and Vogt PK: Oncogenic transformation induced by the p110beta, -gamma, and -delta isoforms of class I phosphoinositide 3-kinase. Proc Natl Acad Sci USA 103: 1289-1294, 2006.

7. Chen H, Mei L, Zhou L, Shen X, Guo C, Zheng Y, Zhu H, Zhu Y and Huang L: PTEN restoration and PIK3CB knockdown synergistically suppress glioblastoma growth in vitro and in xenografts. J Neurooncol 104: 155-167, 2011.

8. Edgar KA, Wallin JJ, Berry M, Lee LB, Prior WW, Sampath D, Friedman LS and Belvin M: Isoform-specific phosphoinositide 3-kinase inhibitors exert distinct effects in solid tumors. Cancer Res 70: 1164-1172, 2010.

9. Zhu Q, Youn H, Tang J, Tawfik O, Dennis K, Terranova PF, Du J, Raynal P, Thrasher JB and Li B: Phosphoinositide 3-OH kinase p85alpha and p110beta are essential for androgen receptor transactivation and tumor progression in prostate cancers. Oncogene 27: 4569-4579, 2008.

10. Chen R, Zhao Y, Huang Y, Yang Q, Zeng X, Jiang W, Liu J, Thrasher JB, Forrest ML and Li B: Nanomicellar TGX221 blocks xenograft tumor growth of prostate cancer in nude mice. Prostate 75: 593-602, 2015.

11. Lee SH, Poulogiannis G, Pyne S, Jia S, Zou L, Signoretti S, Loda M, Cantley LC and Roberts TM: A constitutively activated form of the p110beta isoform of PI3-kinase induces prostatic intraepithelial neoplasia in mice. Proc Natl Acad Sci USA 107: 11002-11007, 2010.

12. Jia S, Liu Z, Zhang S, Liu P, Zhang L, Lee SH, Zhang J, Signoretti S, Loda M, Roberts TM, et al: Essential roles of PI(3)K-p110beta in cell growth, metabolism and tumorigenesis. Nature 454: 776-779, 2008.

13. Jiang X,Chen S,Asara JM and Balk SP: Phosphoinositide 3-kinase pathway activation in phosphate and tensin homolog (PTEN)deficient prostate cancer cells is independent of receptor tyrosine kinases and mediated by the p110beta and p110delta catalytic subunits. J Biol Chem 285: 14980-14989, 2010.

14. Fruman DA, Meyers RE and Cantley LC: Phosphoinositide kinases. Annu Rev Biochem 67: 481-507, 1998. 
15. Wee S, Lengauer $\mathrm{C}$ and Wiederschain D: Class IA phosphoinositide 3-kinase isoforms and human tumorigenesis: Implications for cancer drug discovery and development. Curr Opin Oncol 20: 77-82, 2008

16. Shayesteh L, Lu Y, Kuo WL, Baldocchi R, Godfrey T, Collins C Pinkel D, Powell B, Mills GB and Gray JW: PIK3CA is implicated as an oncogene in ovarian cancer. Nat Genet 21: 99-102, 1999.

17. Ma YY, Wei SJ, Lin YC, Lung JC, Chang TC, Whang-Peng J, Liu JM, Yang DM, Yang WK and Shen CY: PIK3CA as an oncogene in cervical cancer. Oncogene 19: 2739-2744, 2000.

18. Samuels Y, Wang Z, Bardelli A, Silliman N, Ptak J, Szabo S, Yan H, Gazdar A, Powell SM, Riggins GJ, et al: High frequency of mutations of the PIK3CA gene in human cancers. Science 304 554, 2004.

19. Campbell IG, Russell SE, Choong DY, Montgomery KG, Ciavarella ML, Hooi CS, Cristiano BE, Pearson RB and Phillips WA: Mutation of the PIK3CA gene in ovarian and breast cancer. Cancer Res 64: 7678-7681, 2004.

20. Wu G, Mambo E, Guo Z, Hu S, Huang X, Gollin SM, Trink B Ladenson PW, Sidransky D and Xing M: Uncommon mutation, but common amplifications, of the PIK3CA gene in thyroid tumors. J Clin Endocrinol Metab 90: 4688-4693, 2005.

21. Phillips WA, Russell SE, Ciavarella ML, Choong DY, Montgomery KG, Smith K, Pearson RB, Thomas RJ and Campbell IG: Mutation analysis of PIK3CA and PIK3CB in esophageal cancer and Barrett's esophagus. Int J Cancer 118: 2644-2646, 2006.

22. Pu P, Kang C, Zhang Z, Liu X and Jiang H: Downregulation of PIK3CB by siRNA suppresses malignant glioma cell growth in vitro and in vivo. Technol Cancer Res Treat 5: 271-280, 2006.

23. An HJ, Cho NH, Yang HS, Kwak KB, Kim NK, Oh DY, Lee SW, Kim HO and Koh JJ: Targeted RNA interference of phosphatidylinositol 3-kinase p110-beta induces apoptosis and proliferation arrest in endometrial carcinoma cells. J Pathol 212: 161-169, 2007

24. Oda K, Okada J, Timmerman L, Rodriguez-Viciana P, Stokoe D, Shoji K, Taketani Y, Kuramoto H, Knight ZA, Shokat KM, et al: PIK3CA cooperates with other phosphatidylinositol 3'-kinase pathway mutations to effect oncogenic transformation. Cancer Res 68: 8127-8136, 2008

25. Wee S, Wiederschain D, Maira SM, Loo A, Miller C, deBeaumont R, Stegmeier F, Yao YM and Lengauer C: PTENdeficient cancers depend on PIK3CB. Proc Natl Acad Sci USA 105: 13057-13062, 2008.

26. Jackson SP, Schoenwaelder SM, Goncalves I, Nesbitt WS, Yap CL, Wright CE, Kenche V, Anderson KE, Dopheide SM, Yuan Y, et al: PI 3-kinase p110ß: A new target for antithrombotic therapy. Nat Med 11: 507-514, 2005.
27. Lin H, Erhard K, Hardwicke MA, Luengo JI, Mack JF, McSurdy-Freed J, Plant R, Raha K, Rominger CM, Sanchez RM, et al: Synthesis and structure-activity relationships of imidazo[1,2-a]pyrimidin-5(1H)-ones as a novel series of beta isoform selective phosphatidylinositol 3-kinase inhibitors. Bioorg Med Chem Lett 22: 2230-2234, 2012.

28. Luo J, Manning BD and Cantley LC: Targeting the PI3K-Akt pathway in human cancer: Rationale and promise. Cancer Cell 4 : 257-262, 2003

29. Sturgeon SA, Jones C, Angus JA and Wright CE: Advantages of a selective beta-isoform phosphoinositide 3-kinase antagonist, an anti-thrombotic agent devoid of other cardiovascular actions in the rat. Eur J Pharmacol 587: 209-215, 2008.

30. Bird JE, Smith PL, Bostwick JS, Shipkova P and Schumacher WA: Bleeding response induced by anti-thrombotic doses of a phosphoinositide 3-kinase (PI3K)- $\beta$ inhibitor in mice. Thromb Res 127: 560-564, 2011.

31. Garcia A, Kim S, Bhavaraju K, Schoenwaelder SM and Kunapuli SP: Role of phosphoinositide 3-kinase $\beta$ in platelet aggregation and thromboxane $A_{2}$ generation mediated by $G_{i}$ signalling pathways. Biochem J 429: 369-377, 2010.

32. Roche S, Downward J, Raynal P and Courtneidge SA: A function for phosphatidylinositol 3-kinase beta (p85alpha-p110beta) in fibroblasts during mitogenesis: Requirement for insulin- and lysophosphatidic acid-mediated signal transduction. Mol Cell Biol 18: 7119-7129, 1998.

33. Hooshmand-Rad R, Hájková L, Klint P, Karlsson R, Vanhaesebroeck B, Claesson-Welsh L and Heldin CH: The PI 3-kinase isoforms p110(alpha) and p110(beta) have differential roles in PDGF- and insulin-mediated signaling, J Cell Sci 113 Pt 2: 207-214, 2000.

34. Asano T, Kanda A, Katagiri H, Nawano M, Ogihara T, Inukai K, Anai M, Fukushima Y, Yazaki Y, Kikuchi M, et al: p110beta is up-regulated during differentiation of 3T3-L1 cells and contributes to the highly insulin-responsive glucose transport activity. J Biol Chem 275: 17671-17676, 2000.

35. Kubo H, Hazeki K, Takasuga S and Hazeki O: Specific role for $\mathrm{p} 85 / \mathrm{p} 110$ beta in GTP-binding-protein-mediated activation of Akt. Biochem J 392: 607-614, 2005.

36. Kurosu H, Maehama T, Okada T, Yamamoto T, Hoshino S, Fukui Y, Ui M, Hazeki O and Katada T: Heterodimeric phosphoinositide 3-kinase consisting of p85 and p110beta is synergistically activated by the betagamma subunits of $\mathrm{G}$ proteins and phosphotyrosyl peptide. J Biol Chem 272: 24252-24256, 1997. 